
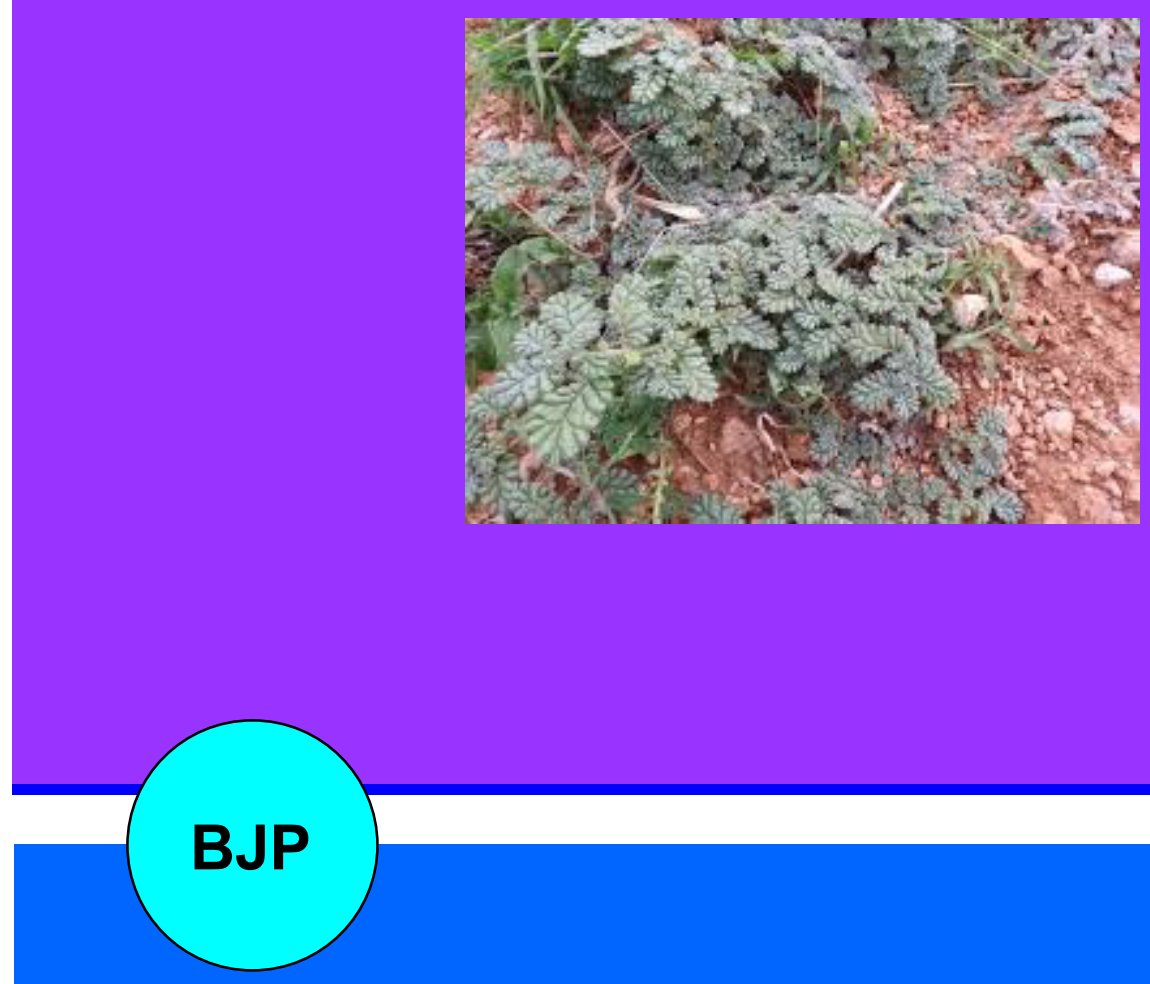

Bangladesh Journal of Pharmacology

Research Article

Ethnopharmacological studies on Chrozophora prostrata in perspective of its folkloric reputation as purgative 


\title{
Ethnopharmacological studies on Chrozophora prostrata in perspective of its folkloric reputation as purgative
}

\author{
Usman Arshad1,2, Khalid Hussain Janbaz', Samra Bashir3, Najeeb-Ur-Rehman3, Malik \\ Hassan Mehmood3 and Anwar-Ul-Hassan Gilani 3
}

${ }^{1}$ Faculty of Pharmacy, Bahauddin Zakariya University, Multan; ${ }^{2}$ Department of Pharmacy, COMSATS Institute of Information Technology, Abbottabad; ${ }^{3}$ Natural Product Research Division, Department of Biological and Biomedical Sciences, Aga Khan University Medical College, Karachi 74 800, Pakistan.

\begin{tabular}{|c|c|}
\hline \multicolumn{2}{|l|}{ Article Info } \\
\hline Received: & 24 October 2012 \\
\hline Accepted: & 25 October 2012 \\
\hline Available Online: & 26 October 2012 \\
\hline \multicolumn{2}{|c|}{ DOI: 10.3329/bjp.v7i4.12351 } \\
\hline \multicolumn{2}{|c|}{$\begin{array}{l}\text { Cite this article: } \\
\text { Arshad U, Janbaz KH, Bashir S, } \\
\text { Rehman NU, Mehmood MH, Gilani } \\
\text { AUH. Ethnopharmacological studies } \\
\text { on Chrozophora prostrata in perspective } \\
\text { of its folkloric reputation as purga- } \\
\text { tive. Bangladesh J Pharmacol. 2012; } 7 \text { : } \\
\text { 243-48. }\end{array}$} \\
\hline
\end{tabular}

\begin{abstract}
This study was undertaken to validate the medicinal use of Chrozophora prostrata in constipation. The crude extract of C prostrata produced laxative effect in mice at 100 and $300 \mathrm{mg} / \mathrm{kg}$, similar to carbachol and castor oil. In spontaneously contracting rabbit jejunum tissues, C. prostrata $(0.01-3 \mathrm{mg} / \mathrm{mL})$ exhibited atropine-sensitive spasmogenic effect, which was reproducible in guinea-pig ileum. Interestingly, at high concentrations, C. prostrata showed concentration-dependent inhibitory effect on rabbit jejunum, suggesting the presence of accompanied spasmolytic activity. When tested on induced contractions, C. prostrata completely relaxed low $\mathrm{K}^{+-i n d u c e d ~ c o n t r a c t i o n, ~}$ while partially inhibited high $\mathrm{K}^{+}$, similar to cromakalim. Tetraethylammonium pretreatment abolished the relaxant effect of C. prostrata on low $\mathrm{K}^{+}$-induced contractions while glibenclamide caused partial inhibition, suggesting the involvement of some non-specific and ATP-dependent $\mathrm{K}^{+}$ channels. These data show that C. prostrata possesses laxative effect at low doses mediated through cholinergic action followed by the spasmolytic activity at high doses mediated possibly through $\mathrm{K}^{+}$channel activation.
\end{abstract}

\section{Introduction}

Chrozophora prostrate (C. prostrata), Dalz. (Family; Euphorbiaceae) is locally known as Nilkanthi (Caius, 1986). It grows in water logged areas and river banks as well as the dried areas of Pakistan (Caius, 1986; Nasir and Ali, 1986). It is known to be rich in leucoanthocyanidin, flavonoid and coumarin derivatives. Two xanthone glycosides i.e., 3,5,6,7,8-pentamethoxyzanthone-1-O-rhamnosyl $(1 \rightarrow 6)$ glucopyranoside and 3,5,8trimethoxyxanthone-1-O-glucopyranoside as well as a chromone glycoside i.e., 2-acetonyl-5-methyl-7-hydroxy -6-C-glucopyranosyl chromone-2"-O-glucopyranoside have been identified from the roots of $C$. prostrata (Agrawal and Singh, 1988).
Different parts of the plant have extensively been used in the native system of medicine to treat various kinds of ailments. The leaves are presumed to possess depurative properties (Evan, 2002) and the seeds are known to possess laxative and alterative properties (Nadkarni, 1976). Ash of the root is used to manage cough in children (Kritkar and Basu, 1975). Decoction made from the plant has been employed to control leprous affections (Said, 1972). It is also regarded as blood purifier and used for the treatment of chronic persistent fever, syphilis, gonorrhea as well as leucoderma (Awan, 1993).

The present study was undertaken to evaluate the folkloric repute laxative activity of C. Prostrata to 
rationalize its medicinal use by using both the in vitro and in vivo models.

\section{Materials and Methods}

\section{Plant material and the extraction procedure}

The dried plant material was purchased from a local herbal store in Multan, Pakistan and was identified by a taxonomist, Ms Saima Shehzadi, of the Institute of Pure and Applied Biology, Bahauddin Zakariya University, Multan. A specimen of the plant has been deposited at Herbarium at the Department of Biological and Biomedical Sciences Aga Khan University, Karachi, against voucher number Cp. A. 06-08-119. The herbal material was rendered free of any adulterant through manual picking and was ground to a coarse powder by an electrical grinder. Approximately $1 \mathrm{~kg}$ coarsely powdered plant material was soaked in the $80 \%$ aqueous-ethanol for one week with occasional shaking. It was passed through a double layer of muslin cloth and the obtained fluid was subsequently filtered through a Whatman grade 1 filter paper. The collected filtrate was concentrated on rotary evaporator (R-210, $\mathrm{BUCHI}$, Switzerland) under reduced pressure at $37^{\circ} \mathrm{C}$ to a thick, semi- solid mass, i.e., the crude ethanolic extract with the approximate yield of $8.3 \%$.

\section{Animals}

Rabbits and mice of local breed and either sex were used in the experiments and were kept at the animal house of Aga Khan University, Karachi, at $23-25^{\circ} \mathrm{C}$. Animals were provided with standard diet and tap water ad libitum but were subjected to 24 hours starvation prior to the experiments. Rabbits were sacrificed by a blow on the back of head for the in vitro experiments on gut tissues, while mice were used for the in vivo laxative study and acute toxicity testing. The animals were used in line with the guidelines of the Institute of Laboratory Animal Resources, Commission on Life Sciences, National Research Council (NRC, 1996).

\section{Chemicals}

The following chemicals were obtained from the sources specified: Acetylcholine chloride, atropine sulfate, potassium chloride, carbachol, cromakalim, glibenclamide, and tetraethyl ammonium chloride (TEA) from Sigma Chemicals Co. USA. Calcium chloride, glucose, magnesium chloride, sodium bicarbonate, sodium dihydrogen phosphate, hydrochloric acid, ethanol, acetic anhydride, ether, benzene and chloro-form from Merck, Darmstadt, Germany, while sodium chloride, sodium hydroxide and ammonium hydroxide from BDH Laboratory supplies, Poole, England. All chemicals used in these experiments were of the highest purity and research grade. Stock solutions of all chemicals were prepared in normal saline, except cromakalim and glibenclamide which were dissolved in 10\% DMSO (di-methyl sulfoxide) and the volume made up by normal saline. The vehicle used for solubilization of drugs had no effect on tissue contractility in the control experiments. The stock solutions and their dilutions were made fresh on the day of experiment.

\section{In vivo experiments}

Mice were used as the in vivo animal models for the evaluation of laxative activity in test materials in comparison to castor oil and carbachol as standard diarrhea inducers. Mice were deprived of food for 24 hours prior to the experiment but had free access to water. Twenty five animals were divided into five groups, each containing five mice. Each mouse was kept in a separate cage over a blotting sheet for convenience in fecal counting. Group1 $1^{\text {st }}$ animals, considered as the negative control, were treated orally with normal saline $(10 \mathrm{~mL} / \mathrm{kg})$, group $2^{\text {nd }}$ and $3^{\text {rd }}$, the positive controls, with castor oil $(10 \mathrm{~mL} / \mathrm{kg})$ and carbachol (2 mg/kg), respectively, while the animal of group $4^{\text {th }}$ and group $5^{\text {th }}$, labeled as the test groups, received oral doses of 100 and $300 \mathrm{mg} / \mathrm{Kg}$ of C. prostrata respectively. Total number of feces was counted for each mouse separately and calculated the average number of feces for each group.

\section{In vitro experiments}

The effect of C. prostrata on gut motility was studied in isolated rabbit jejunum and guinea-pig ileum preparations as described previously (Shah et al., 2011). Approximately $2 \mathrm{~cm}$ long segments of jejunum or ileum were suspended in tissue baths containing Tyrode's solution maintained at $37^{\circ} \mathrm{C}$ and aerated with carbogen

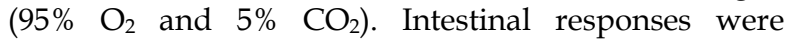
recorded isotonically using Bioscience transducers attached to an Oscillograph and Powerlab Data Acquisition System (AD Instruments, Sydney, Australia) linked to a computer installed with Labchart software (version 6). The tissues were allowed to equilibrate for $30 \mathrm{~min}$ prior to addition of any chemical substance. The tissues were stabilized following repeated exposure to acetylcholine $(0.3 \mu \mathrm{M})$ after washing with the Tyrode's solution until the submaximal responses of uniform amplitude were obtained. The observed modulation of spontaneous rhythmic contractions was used to test spasmolytic or spasmogenic activity in spontaneously contracting isolated rabbit jejunum preparation, whereas, induction of contraction with test or control drugs above that of the basal tone was used to measure spasmogenic activity in guinea-pig ileum.

\section{Acute toxicity testing}

Mice were used for assessment of the acute toxicity. The animals were fasted 24 hours prior to experimentation 
but allowed free access to water. Twenty mice were divided into four groups each containing five animals. Group 1 was given normal saline $(0.9 \%$ sodium chloride) orally and considered as the control group. Group 2, 3 and 4 were orally administered with 3,5 and $7 \mathrm{~g} /$ $\mathrm{Kg}$ of C. prostrata, respectively. All the groups were observed for 24 hours for possible lethargy and mortality.

\section{Statistical analysis}

The data are expressed as the mean \pm standard error of the mean (SEM) and the median effective concentrations ( $\mathrm{EC}_{50}$ values) with $95 \%$ confidence intervals (CI). The statistical test applied is the Student's t-test and $\mathrm{p}<0.05$ is considered as significantly different.

\section{Results}

Oral administration of castor oil $(10 \mathrm{~mL} / \mathrm{kg})$ and carbachol $(2 \mathrm{mg} / \mathrm{kg}$ ) to mice resulted in significant laxative effect with mean fecal count of $10.6 \pm 2.0$ and $10.2 \pm 0.6$ respectively, as compared to $5.2 \pm 1.5$ with saline. In the test groups, treatment with 100 and 300 $\mathrm{mg} / \mathrm{kg} \mathrm{C}$. prostrata exhibited dose-dependent laxative effect with respective mean fecal count of $8.2 \pm 1.0$ and $13.4 \pm 2.5$ (Figure 1).

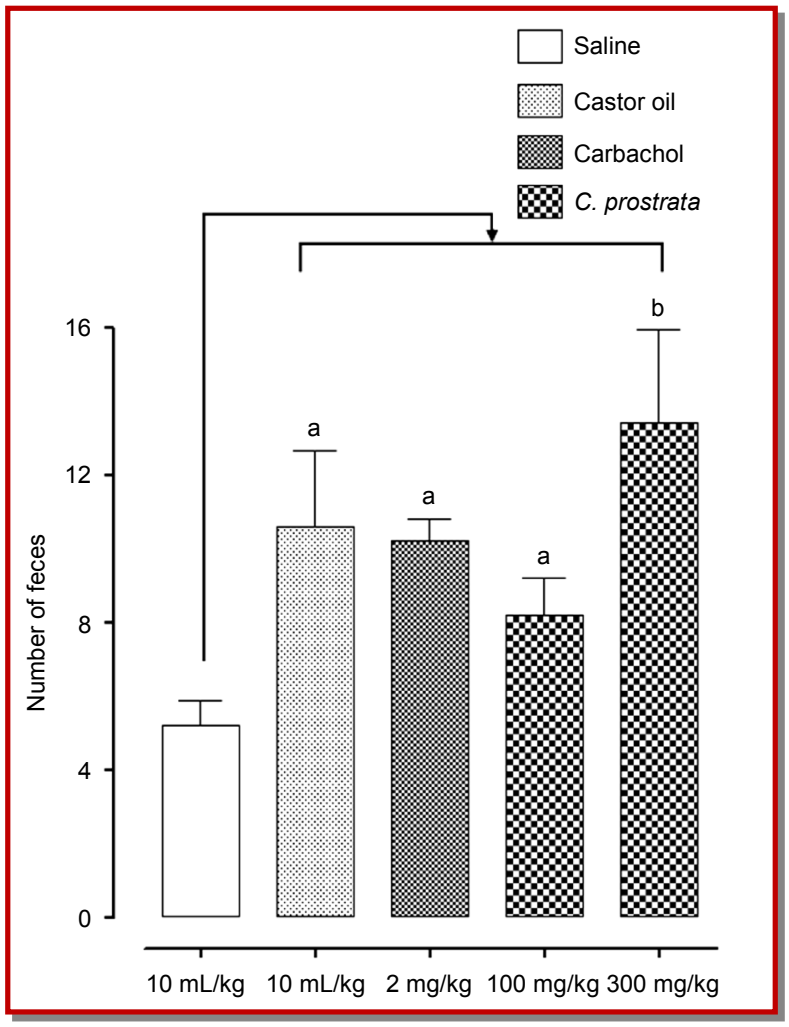

Figure 1: Comparative laxative effect of 100 and $300 \mathrm{mg} / \mathrm{kg}$ crude extract of C. prostrata, castor oil (10) and carbachol (2 mg/ $\mathrm{Kg})$ against normal saline $(10 \mathrm{~mL} / \mathrm{kg})$ in healthy mice. ${ }^{\mathrm{a}} \mathrm{p}<0.05$, ${ }^{\mathrm{b}} \mathrm{p}<0.01$ vs. Saline group
Application of C. prostrata on spontaneously contracting rabbit jejunum exhibited biphasic response i.e., initial concentration-dependant $(0.01-0.3 \mathrm{mg} / \mathrm{mL})$ excitation followed by the concentration-dependant inhibition of the spontaneous contractions $(1-3 \mathrm{mg} / \mathrm{mL})$. The spasmogenic effect of $C$. prostrata was suppressed by pretreatment of the tissues with $0.1 \mu \mathrm{M}$ atropine (Figure $2 \mathrm{a})$. C. prostrata caused relaxation of low $\mathrm{K}^{+}(25 \mathrm{mM})$ induced contractions with $\mathrm{EC}_{50}$ value of $0.2 \mathrm{mg} / \mathrm{mL}(0.2$ $-0.3,95 \% \mathrm{CI})$ whereas, it caused partial relaxation of high $\mathrm{K}^{+}(80 \mathrm{mM})$-induced contractions, similar to cromakalim (Figure 2A and B). When applied on guinea -pig ileum, C. prostrata caused contractions in a concentration-dependent manner. The respective contractions at $0.3,1,3$ and $10 \mathrm{mg} / \mathrm{mL}$ were recorded as $7.7 \pm 1.4,15.0 \pm 2.9,34.7 \pm 2.9$ and $54.7 \pm 4.7 \%$ of the ACh -induced maximum response (Figure 3). Pre-incubation of the tissue with atropine $0.1 \mu \mathrm{M}$ abolished the spasmogenic effect of C. prostrata, like that of acetylcholine.

The inhibitory effect of C. prostrata was blocked in the tissues pretreated with TEA $(10 \mathrm{mM})$ while partially reversed in the glibenclamide $(30 \mu \mathrm{M})$ pretreated preparations. The inhibitory effect of cromakalim on low $\mathrm{K}^{+}$-induced contractions was completely inhibited in the tissue pretreated with glibenclamide (Figure 4A and B).

The oral dose of C. prostrata as high as $7 \mathrm{mg} / \mathrm{Kg}$, did not produce lethality among the treated groups of mice.

\section{Discussion}

C. prostrata was subjected to pharmacological investigation in order to validate its folkloric repute in constipation (Nadkarni, 1976). When studied for its laxative effect in mice, C. prostrata enhanced fecal production similar to CCh. To study the possible mode of action of its laxative activity, the aqueous ethanolic plant extract was tested on spontaneously contracting rabbit jejunum preparations, where it produced atropine-sensitive spasmogenic effect at lower concentrations, indicating possible presence of gut stimulatory component(s). The spasmogenic effect of C. prostrata was further studied on guinea-pig ileum, a quiescent preparation considered useful for this purpose (Bashir et al., 2006). The plant extract produced contractions in ileum preparations which were also blocked in the presence of atropine, thus confirming the presence of spasmogenic effect in C. prostrata mediated possibly through stimulation of cholinergic receptors, similar to $\mathrm{ACh}$, which is known to have excitatory action on gut segments (Brown and Taylor, 2006). The spasmodic effect observed at low concentrations in rabbit jejunum was moderate when compared with ACh-induced maximum contractions. 


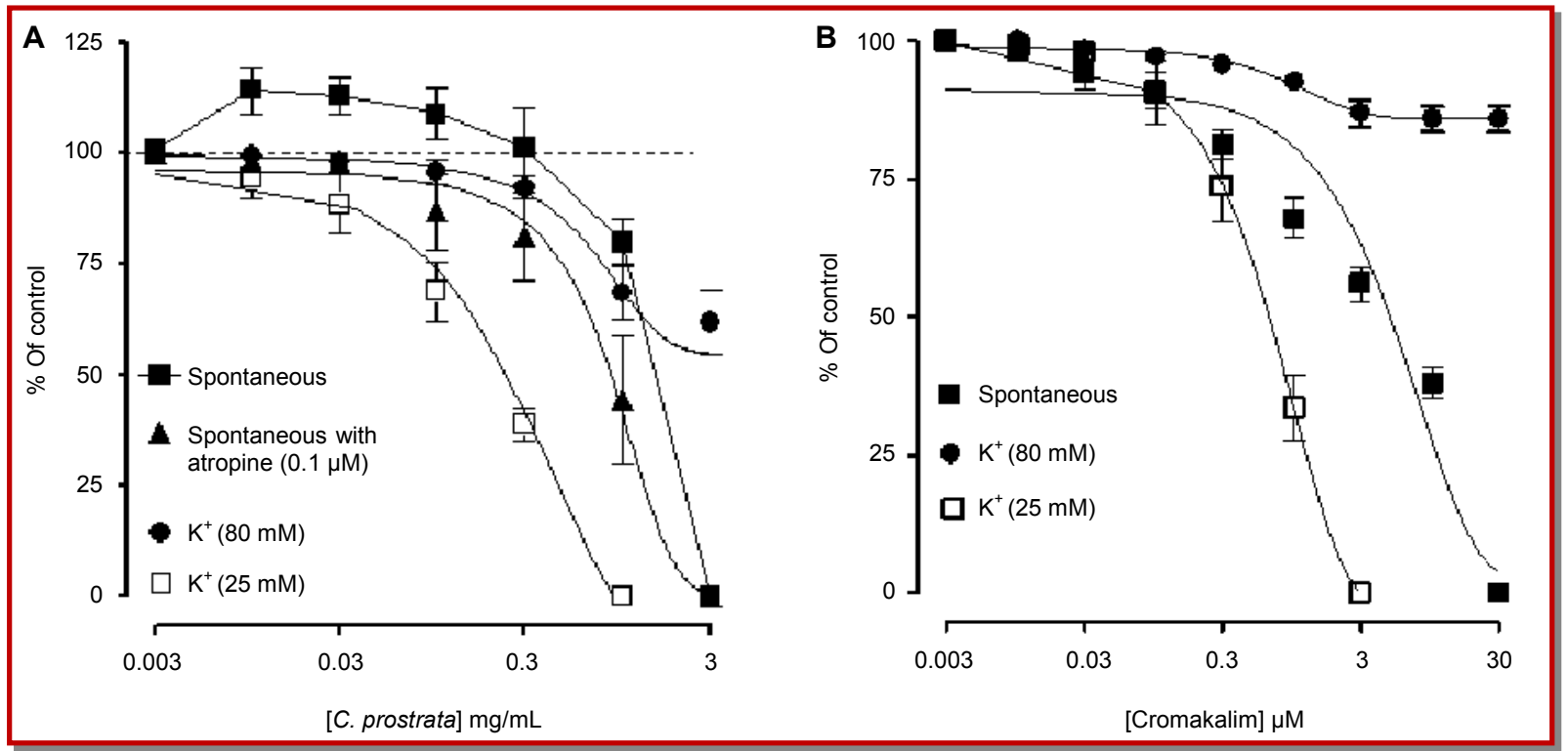

Figure 2: Effect of crude extract of C. prostrata on spontaneous, atropine $(0.1 \mu \mathrm{M})$ incubated spontaneous, $\mathrm{K}^{+}(80 \mathrm{mM})$ and $\mathrm{K}^{+}(25$ $\mathrm{mM}$ )-induced contractions (A) and that of cromakalim on spontaneous, $\mathrm{K}^{+}(80 \mathrm{mM})$ and $\mathrm{K}^{+}(25 \mathrm{mM})$ induced contractions (B) in isolated rabbit jejunum preparations (values expressed are mean \pm SEM for $n=5$ )

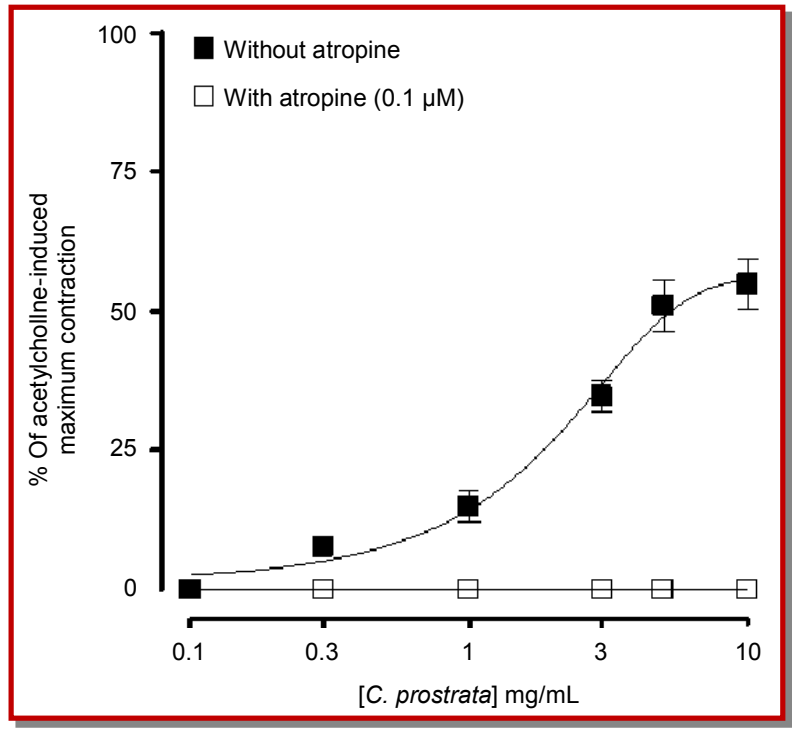

Figure 3: Concentration-dependent spasmogenic effect of crude extract of $C$. prostrata in the absence and presence of atropine $(0.1 \mu \mathrm{M})$ in isolated guinea-pig ileum. The responses are given as $\%$ of acetylcholine $(10 \mu \mathrm{M})$ induced maximum contraction (ACh Max.). The values are shown as mean \pm SEM, $\mathrm{n}=4$

Interestingly at higher concentrations, C. prostrata failed to produce spasmogenic effect and showed dosedependent spasmolytic activity which is perhaps meant by nature to offset the excessive stimulation of gut motility which could be harmful through causing abdominal cramps, as seen with chemical drugs used as laxative (Pasricha, 2008). The observed spasmolytic effect of the plant extract when investigated for possible mechanisms, it showed selective inhibition of low $\mathrm{K}^{+}$ induced contractions while a weak inhibitory influence was observed against high $\mathrm{K}^{+}$. As the plant extract was capable to cause complete relaxation of low $\mathrm{K}^{+}$-induced spastic contractions, hence, it can be speculated that some of the plant components may possibly exert their effect through opening of $\mathrm{K}^{+}$channels (Hamilton et al., 1986; Kishii et al., 1992; Khan et al., 2011). $\mathrm{K}^{+}$channel openers produce smooth muscle relaxation via decreased intracellular free $\mathrm{Ca}^{2+}$ mediated by hyper-polarization of membrane through increased $\mathrm{K}^{+}$efflux on opening of $\mathrm{K}^{+}$channels (Quest and Cook, 1989; Weston and Edwards, 1992).

To know the nature of $\mathrm{K}^{+}$-channels involved in the antispasmodic effect of the plant extract, its relaxant effect against low $\mathrm{K}^{+}$was reproduced in the presence of TEA, a nonspecific $\mathrm{K}^{+}$-channel blocker (Wu et al., 2004) and glibenclamide, an ATP-dependent $\mathrm{K}^{+}$-channel blocker (Frank et al., 1994). TEA completely inhibited the inhibitory effect of C. Prostrata, while glibenclamide showed partial inhibition, showing the predominant involvement of non-specific $\mathrm{K}^{+}$-channel activation and the partial involvement of the specific ATP-dependent $\mathrm{K}^{+}$-channels. On the other hand, the inhibitory effect of cromakalim, a specific ATP-dependent $\mathrm{K}^{+}$-channel opener (Escande et al., 1988), was completely inhibited when studied in tissues pretreated with glibenclamide.

C. prostrata was found safe in mice up to the dose of as high as $7 \mathrm{~g} / \mathrm{kg}$ indicating that it is relatively safe for short term use, though further chronic toxicity testing is required to know the true safety profile.

These data indicate that $C$. prostrata possesses laxative and gut stimulant properties possibly mediated 

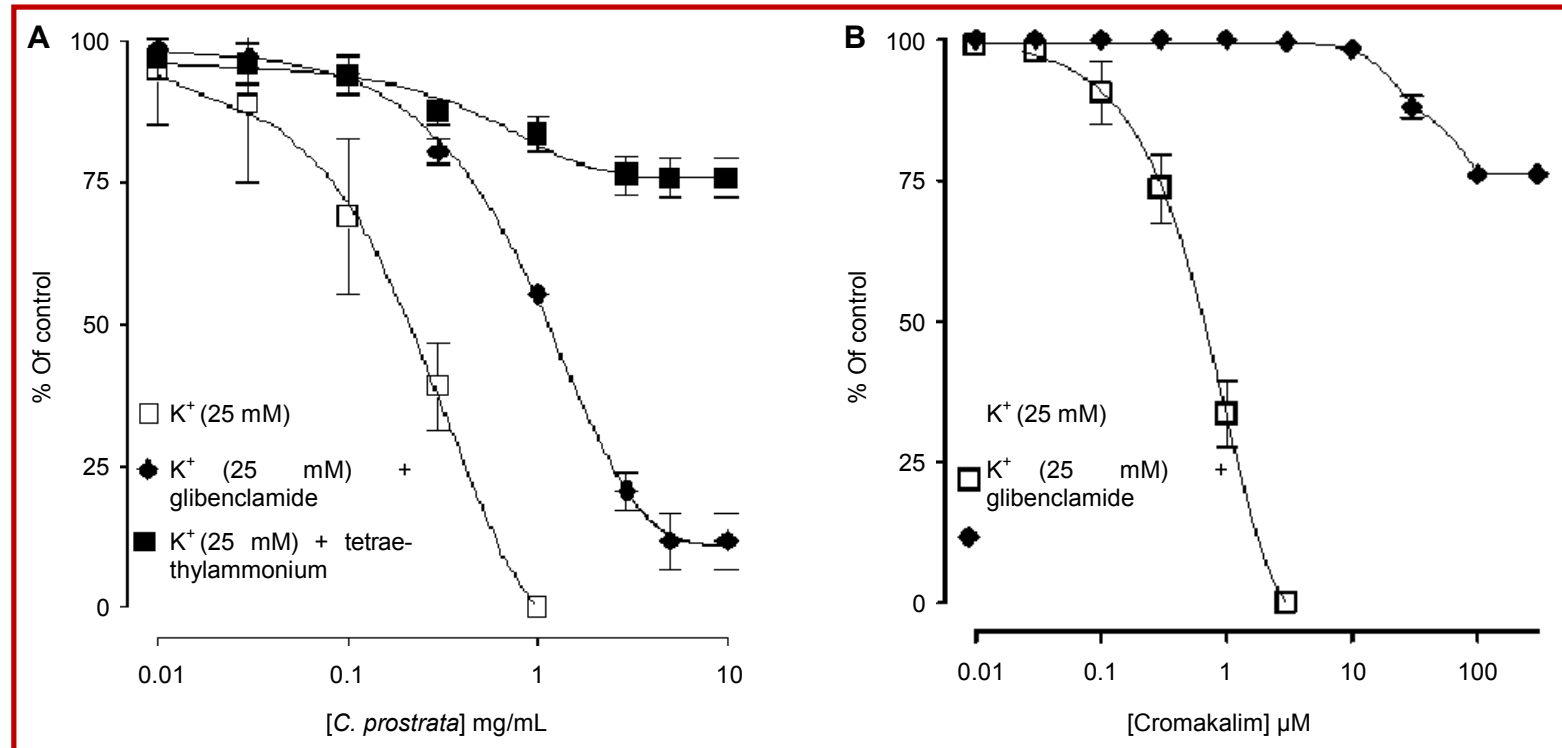

Figure 4: Effect of crude extract of C. prostrata (A) and cromakalim (B) against $\mathrm{K}^{+}(25 \mathrm{mM})$-induced contractions in the absence of any $\mathrm{K}^{+}$channel antagonist and in the presence of tetraethylammonium chloride (TEA; $\left.10 \mathrm{mM}\right)$ and glibenclamide $(\mathrm{GB} ; 30 \mu \mathrm{M})$ in isolated rabbit jejunum preparations (values expressed are mean \pm SEM for $n=4$ )

through cholinergic receptor stimulation. However, the accompanied spasmolytic effect observed at high doses was found mediated through non-specific and ATPsensitive $\mathrm{K}^{+}$-channel activation and was perhaps meant by nature to offset the excessive stimulation which could have been harmful.

\section{Acknowledgment}

This study was supported in part by the Pakistan Medical Research Council (Grant \# 4-22-5/05/RDC/AKU).

\section{References}

Agrawal A, Singh J. Glycosides of two xanthones and a chromone from roots of Chrozophora prostrata. Phytochem. 1988; 27: 3692-94.

Awan HMH. Kitab-ul-mufridat. Lahore, Sheikh Ghulam Ali and Sons, 1993, p 500.

Bashir S, Janbaz KH, Jabeen Q, Gilani AH. Studies on spasmogenic and spasmolytic activities of Calendula officinalis flowers. Phytother Res. 2006; 20: 906-10.

Brown JH, Taylor P. Cholinergic agonists. In Goodman and Gilman's The Pharmacological basis of therapeutics. 11 th ed. Brunton LL, Lazo JS, Parker KL (eds). New York, McGrawHill, 2006, pp 845-68.

Caius JF. The medicinal and poisonous plants of India. Jodhpur, Scientific publishers, 1986, p 276.

Escande D, Thuringer D, Leguern S, Cavero I. The potassium channel opener cromakalim (BRL34915) activates ATPdependent $\mathrm{K}^{+}$channels in isolated cardiac myocytes. Biochem Biophys Res Commun. 1988; 154: 620-25.
Evan WC. Trease and Evan's pharmacognosy. 15th ed. Edenburgh, Harcourt publishers, 2002, p 473.

Frank H, Puschmann A, Schusdziarra V, Allescher HD. Functional evidence for a glibenclamide-sensitive $\mathrm{K}^{+}$channel in rat ileal smooth muscle. Eur J Pharmacol. 1994; 271: 379-86.

Hamilton TC, Weir SW, Weston TH. Comparison of the effects of BRL34915 and verapamil on electrical and mechanical activity in rat portal vein. Br J Pharmacol. 1986; 88: 103-11.

Khan A, Rehman NU, AlKharfy KM, Gilani A. Antidiarrheal and antispasmodic activities of Salvia officinalis are mediated through activation of $\mathrm{K}^{+}$channels. Bangl J Pharmacol. 2011; 6: 110-16.

Kishii KI, Morimoto T, Nakajima N, Yamazaki K, Tsujitani M, Takayanagi I. Effect of LP-805, a novel vasorelaxant agent, a potassium channel opener on rat thoracic aorta. Gen Pharmacol. 1992; 23: 347-53.

Nadkarni KM. Indian Materia Medica. 3rd ed. Bombay, Popular Prakashan, 1976, p 310.

Nasir E, Ali SI. Flora of Pakistan. Pakistan, A. Radcliffe-Smith, 1986, pp 47-49.

National Research Council, Guide for the care and use of laboratory animals. Washington, National Academy Press, 1996, pp 1-5.

Pasricha PJ. Treatment of disorders of bowel motility and water flux; antiemetics, agents used in biliary and pancreatic disease. In: Goodman and Gillman's Manual of pharmacology and therapeutics. Brunton L, Parker K, Blumenthal D, Buxton I (eds). 11th ed. New York, McGraw-Hill, 2008, pp 633-52.

Quest U, Cook NS. Moving together: $\mathrm{K}^{+}$channel openers and ATP sensitive $\mathrm{K}^{+}$channels. Trends Pharmacol Sci. 1989; 10: 431-35. 
Said HM. Pharmacographia indica. Volume 15. Pakistan, The Institute of Health and Tibbi Research, 1972, p 409.

Shah AJ, Begum S, Hassan SI, Ali SN, Siddiqui BS, Gilani AH. Pharmacological basis for the medicinal use of Psidium guajava leave in hyperactive gut disorders. Bangladesh J Pharmacol. 2011; 6: 100-06.

Weston AH, Edwards G. Recent progress in potassium channel opener pharmacology. Biochem Pharmacol. 1992; 43: $47-54$

Wu BN, Lin RJ, Lo YC, Shen KP, Wang CC, Lin YT, Chen IJ. KMUP-1, a xanthine derivative, induces relaxation of guinea -pig isolated trachea: The role of epithelium, cyclic nucleotides and $\mathrm{K}^{+}$channels. Br J Pharmacol. 2004; 142: 1105 -14 . 